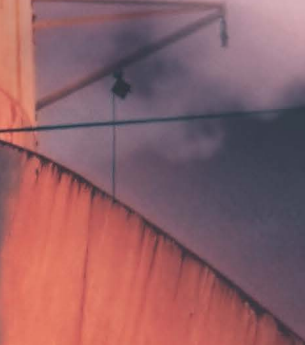

African perspectives on selected marine, maritime and

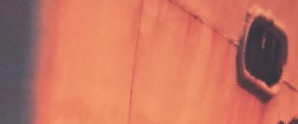

)
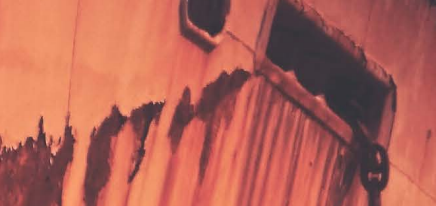

:
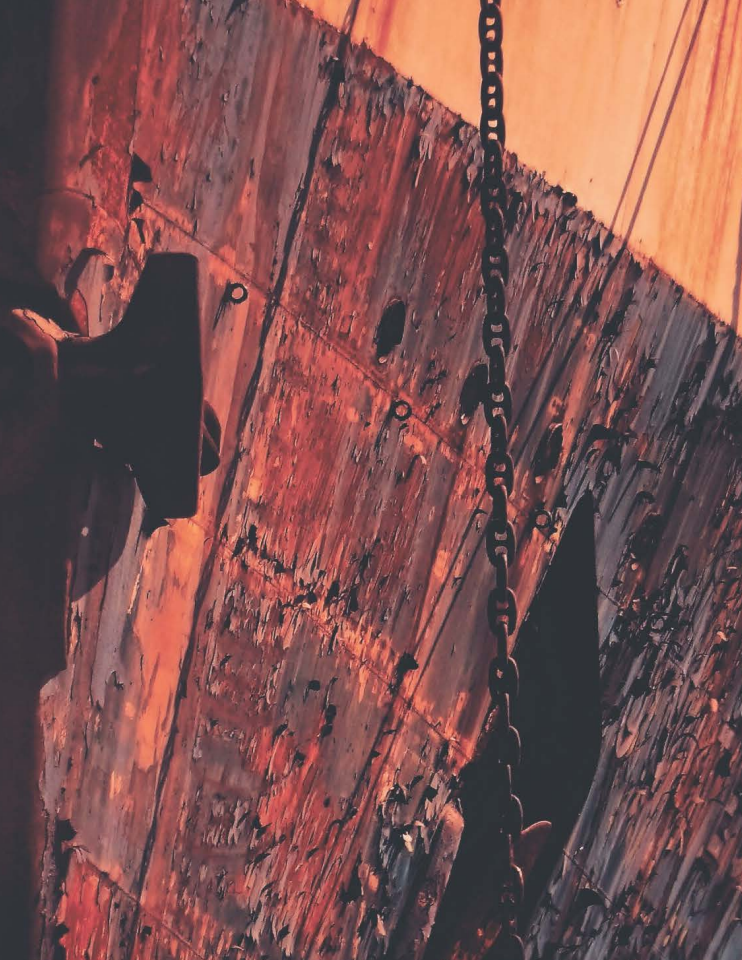

Patrick Vrancken \& Char! Hugo (Eds)

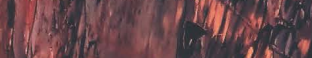

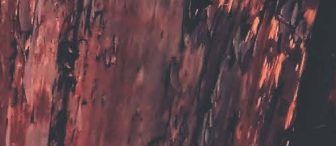
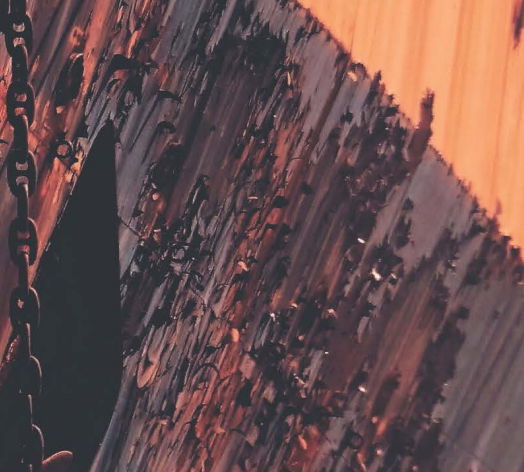


\title{
UTMOST GOOD FAITH IS DEAD, LONG LIVE UTMOST GOOD FAITH? A HISTORICAL OVERVIEW OF GOOD FAITH IN (MARINE) INSURANCE IN ENGLAND AND SOUTH AFRICA
}

\author{
DALEEN MILLARD ${ }^{\star}$ \\ SAMANTHA HUNEBERG ${ }^{\star \star}$
}

* Professor in Private Law, University of Johannesburg.

** Lecturer in Mercantile Law, University of Johannesburg 


\section{INTRODUCTION}

Marine insurance is by all accounts the oldest form of insurance, dating back to the lex mercatoria, which was absorbed into the laws of different countries and resulted, inter alia, in insurance law being almost identical in most countries in Western Europe, including Holland.

Debate in South Africa on the true origins of insurance law was therefore much ado about nothing as, save for the principles that govern some aspects of the actual insurance contract, insurance is insurance! Nevertheless, the then Appellate Division found it necessary to state that the source of South African insurance law is Roman-Dutch law and Mutual \& Federal Insurance Co Ltd $v$ Oudtshoorn Municipality ${ }^{1}$ remains one of the much-quoted precedents on insurance contracts.

Although insurance contracts have always been truly international, the ruling in Oudtshoorn teaches that although English law is not a source of South African insurance law, it has persuasive authority in some matters. In addition, insurance law in modern-day South Africa should be developed with the local markets in mind. Marine insurance, although anchored in the South African legislative framework, takes cognisance of standards in other jurisdictions as vessels inevitably negotiate waters outside the jurisdiction of South African courts. It is also submitted that all marine vessels, regardless of their country of origin, face the same perils once at sea. It is therefore informative to compare the South African perception of good faith in insurance to the English one.

Two recent cases on marine insurance provide examples of the kinds of perils that may be insured against. In the English case of Sealion Shipping Limited and Toisa Horizon Inc v Valiant Insurance Company: The MV "Toisa Pisces", ${ }^{2}$ the insured vessel was an oil production and storage unit which was chartered to a third party. The owners procured so-called "loss of hire" insurance and, because of a series of break-downs, the vessel was placed off-hire for a number of periods, due inter alia to failure of a port motor, a subsequent hydraulics failure which necessitated drydocking and failure of a starboard motor. When the owners instituted a claim, the

1 [1985] 1 All SA 324 (A).

2 [2012] EWHC 50 (Comm); [2012] EWCA Civ 1625. 
insurers refused to pay based on material non-disclosure and want of due diligence. Both the courts of first instance and the court of appeal found the insurers liable. In the trial court, Blair $\mathrm{J}$ stated that the design fault in the engines that was allegedly not disclosed was not material because it would not have caused the insurers to reject the risk. In addition, there was also not a want of due diligence as no negligence pertaining to the vessel could be attributed to the owner. ${ }^{3}$ The court relied on the Canadian decision in Secunda Marine Services v Liberty Mutual. ${ }^{4}$ On appeal, the court relied on the policy wording, came to the same conclusion and, as a result, the issue of non-disclosure was said to be immaterial. This case illustrates that various risks pertaining to marine operations may be insured, including socalled "loss of hire". Whatever the risk, (utmost) good faith plays an important role.

The recent decision in South Africa in Viking Inshore Fishing (Pty) Ltd v Mutual and Federal Insurance Co Ltd ${ }^{5}$ considered the role of promissory warranties in marine insurance and brings a different aspect of good faith to the fore. On 8 May 2005, the fishing vessel Lindsay collided with the Ouro do Brasil off the coast near Cape St Francis. The court ruled that mere breach of a promissory warranty is not itself a ground for repudiation. Rather, if such breach is inconsequential to the loss, it should not be a ground for repudiation. It should be mentioned that the relevance of warranties in the context of good faith is as important as misrepresentation, as warranties in insurance provide the insured with a more favourable alternative than misrepresentation, meaning that insurers may ask policyholders to make a presentation pertaining to certain facts (or warrant something pertaining to the risk, to be more precise). Breach of warranty then constitutes breach of contract and, as was evident in the Viking Inshore case, repudiation based on breach of warranty may be just as problematic as repudiation based on misrepresentation. ${ }^{6}$ In both cases, the right to avoid the contract is restricted by statute. ${ }^{7}$

It is therefore evident that marine insurance is vital to marine enterprises and that all aspects of marine insurance have an international and a domestic-law

\footnotetext{
3 par 69-76.

4 (2006) NSCA 82.

5 [2016] 2 All SA 730 (SCA), 20166 SA 335 (SCA).

6 See par 5.3 below.

7 s 53(1)(a) of the Short-term Insurance Act (53 of 1998).
} 
component, which makes a comparative study of any aspect of marine insurance both interesting and vital. With all this in mind, this contribution aims to sketch the development of the doctrine of utmost good faith from the Marine Insurance Act, 1906 (MIA), to the Insurance Act, 2015, in the United Kingdom and asks whether this doctrine has in fact stood the test of time. In addition, the contribution asks whether the South African approach to good faith in marine insurance in fact yields better results. To this end, this overview will evaluate the most prominent cases in marine insurance over the years and will specifically focus on misrepresentation in marine insurance contracts in England and South Africa. The reader will also find that, because marine insurance in South Africa is (but) a form of short-term or non-life insurance, the principles that apply to marine insurance also apply to all other short-term or non-life insurance contracts, with a few exceptions. ${ }^{8}$ Finally, the contribution evaluates the role of the Financial Advisory and Intermediaries Services Act (FAIS Act), ${ }^{9}$ the Policyholder Protection Rules (PPRs) ${ }^{10}$ and the new Insurance $\mathrm{Act}^{11}$ as legislative instruments that influence good faith in insurance contracts, including marine insurance contracts.

\section{ENGLISH LAW}

\section{The common law position on utmost good faith}

The concept of good faith stemmed from Carter $v$ Boehm, ${ }^{12}$ where Lord Mansfield stated: "Good faith forbids either party by concealing what he privately knows, to draw the other into a bargain, from his ignorance of that fact, and his believing the contrary". ${ }^{13}$

It was in this case that Lord Mansfield introduced certain duties of disclosure for both the insurer and the insured. ${ }^{14}$ The duty to disclose material information,

8 One such exception is that average is a naturale of a marine insurance contract but not of a short-term or noninsurance contract. For the latter, the contract must specifically include an average clause. See Reinecke, Van Niekerk and Nienaber South African Insurance Law (2013) 327.

937 of 2002.

102018

1118 of 2017.

12 (1766) 3 Burr 1905 (97 ER 1162).

13 ibid 1164

14 Lowry "Whither the duty of good faith in UK insurance contracts" 2009 (16) Connecticut Insurance Law Journal 97. 
therefore, underpins the duty of good faith. ${ }^{15}$ The consequence of this is that the general contractual duty expected by both contracting parties to avoid any misrepresentation is extended and reinforced by the additional obligation to disclose all material facts that would induce an insurer to underwrite the specific risk. ${ }^{16}$ In order to understand the principle that emanates from the case, it is insightful to know the facts. Carter was the Governor of Fort Marlborough, a fort that was situated in Indonesia. The fort was built by the British East India Company. Carter took out an insurance policy with Boehm to insure against the fort being taken by a foreign enemy. A witness, Captain Tryon, testified that Carter knew that the fort was built to resist attacks from local enemies, but would be unable to repel European enemies. Apparently, Carter knew that the French were likely to attack the fort and, when they did so successfully, Boehm refused to honour the agreement. It is against these facts that Lord Mansfield explained, in the Carter case,${ }^{17}$ that the policy considerations underlying the duty of disclosure are the prevention of fraud and the furtherance of good faith. The duty, therefore, fulfils mostly a preventative role and is used as a deterrent to acting in bad faith. ${ }^{18}$ Lord Mansfield based the duty upon the concept of "concealment" but, over time, this developed beyond "deliberate concealment" to encompass all types of nondisclosures, even if innocent, of a material fact, ${ }^{19}$ thus drawing distinctions between "deliberate concealments" and misrepresentations (bad faith), on the one hand, and innocent, mistaken non-disclosure (good faith), on the other. ${ }^{20}$

What is interesting to note is that Lord Mansfield avoided the terminology "utmost good faith" in the Carter case; yet this is exactly to what section 17 of the Marine Insurance Act (MIA) ${ }^{21}$ refers. ${ }^{22}$

15 ibid.

16 Lowry (n 14) 98.

17 Carter case (n 12) 1164.

18 Lowry (n 14) 104. See also Re Yager \& Guardian Assurance Co [1912] 108 LT 38 (KB), where Channel J stated that the rationale underlying the duty of disclosure is not the need to prevent harm to the insurer, but the need for a true and fair agreement whereby risk is transferred (44-45).

19 Lowry (n 14) 104.

20 ibid 104-105.

211906.

22 Lowry (n 14) 107. 
The obvious question which comes to mind is when exactly did the disclosure duty morph into "utmost" good faith. The MIA codified the commonlaw principles that had been developed in the eighteenth and nineteenth centuries, largely from marine cases, such as Carter $v$ Boehm, ${ }^{23}$ Noble $v$ Kennoway, ${ }^{24}$ Mayne $v$ Walter $^{25}$ and Friere $v$ Woodhouse. ${ }^{26}$ These cases illustrate that it is in fact the underwriter who is generally the passive recipient of information supplied by the insured when presenting the risk. ${ }^{27}$ Therefore, it is for the insured to supply all the necessary information to the insurer. ${ }^{28}$ The duty of good faith plays a vital role in that it transforms non-disclosures into misrepresentation because an insured who fails to disclose a material fact is essentially misrepresenting the true state of affairs. ${ }^{29}$ What is of importance is that inducement is vital to these two terms: for misrepresentation, the consequence is therefore the same as with untainted nondisclosure, namely avoidance of the contract ab initio. ${ }^{30}$ What is fascinating is that the Carter, Noble, Mayne and Friere cases never directly referred to the principle of "utmost good faith", but rather canvassed various forms of concealments and non-disclosures. ${ }^{31}$ Interestingly, Sir Mackenzie Chalmers was responsible for the codification of a body of case law into the Digest upon which the 1906 Act is based. ${ }^{32} \mathrm{He}$ simply interpreted the case law at the time and this is where utmost good faith was introduced. ${ }^{33}$ The view that insurance required nothing less than utmost good faith became firmly entrenched in English insurance law in this way. ${ }^{34}$ The duty of utmost good faith was subsequently entrenched in section 17 of the MIA.

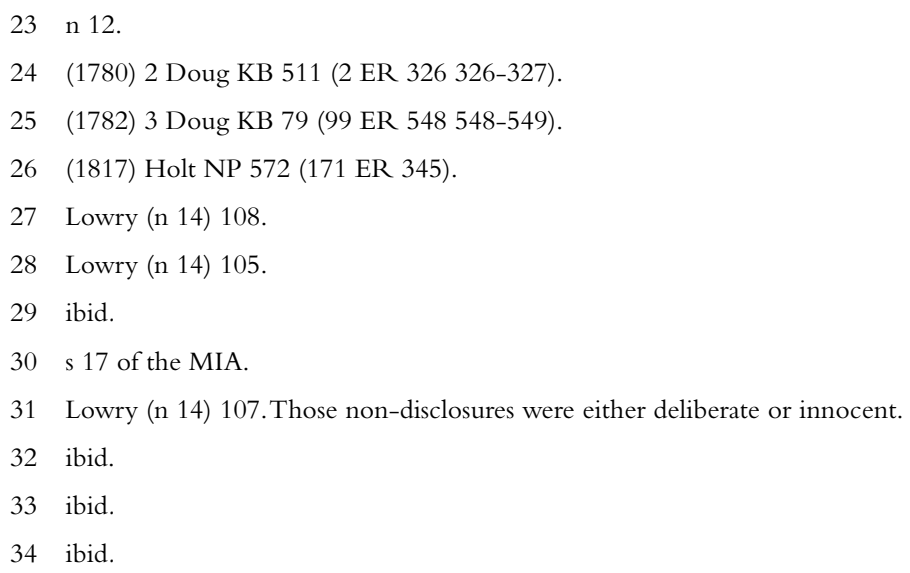


The Marine Insurance Act, 1906

\section{The duty of utmost good faith}

The MIA, as an Act of Parliament regulated not only marine insurance but also other types of insurance ${ }^{35}$ as a codification of English common law. ${ }^{36}$ As was stated in paragraph 2.1 above, this Act saw the codification of the duty of utmost good faith, ${ }^{37}$ which is the cornerstone of insurance law. ${ }^{38}$ To this end, section 17 of the MIA provides:

"A contract of marine insurance is a contract based upon the utmost good faith, and, if the utmost good faith be not observed by either party, the contract may be avoided by the other party". 39

This duty is observed in all insurance contracts and applies before the contract is entered into (that is, at the pre-contractual stage) as well as during the performance of the contract (post-contractual stage, hence a continuing

35 The most important sections of this Act include: 17 (imposes a duty on the insured of uberrima fides; ie that questions must be answered honestly and the risk not misrepresented); 18 ("The assured must disclose to the insurer, before the contract is concluded, every material circumstance which is known to the assured, and the assured is deemed to know every circumstance which, in the ordinary course of business, ought to be known by him. If the assured fails to make such disclosure, the insurer may avoid the contract".); s 33(3) (If [a warranty] be not [exactly] complied with, then, subject to any express provision in the policy, the insurer is discharged from liability as from the date of the breach of warranty, but without prejudice to any liability incurred by him before that date); s 34(2) (where a warranty has been broken, it is no defence to the insured that the breach has been remedied, and the warranty complied with, prior to the loss); s 34(3) (a breach of warranty may be waived by the insurer); 50 (a policy may be assigned); ss 60-63 (deal with the issues of a constructive total loss - by contrast an actual total loss describes the physical destruction of a vessel or cargo); and s 79 (deals with subrogation; ie the rights of the insurer to stand in the shoes of an indemnified insured and recover salvage for his own benefit). Schedule 1 of the Act contains a list of definitions and schedule 2 contains the model policy wording.

36 Law Commission and the Scottish Law Commission Insurance Contract Law: Business Disclosure; Warranties; Insurers' Remedies for Fraudulent Claims and Late Payment (presented to the Parliament of the United Kingdom by the Lord Chancellor and Secretary of State for Justice by Command of Her Majesty, July 2014) (Law Com No 353; Scot Law Com No 238) par 1.16 .

37 ibid par 1.27; Longmore "Good faith and breach of warranty" 2004 Lloyd's Maritime and Commercial Law Quarterly 158 and Ivamy Chalmer's Marine Insurance Act 1906 (1983) 24.

38 Lowry (n 14) 100.

39 Longmore (n 37) 158. See also Birds, Lynch and Milnes MacGillivary on Insurance Law (2014) 453; Bell v Lever Bros Ltd [1932] AC 161227 and Mutual and Federal Insurance Co Ltd v Oudtshoorn Municipality 19851 SA 419 (A) for the South African position. See also s 17 of the MIA 1906 and Birds, Lynch and Milnes (supra) 453. The remedy for a breach of utmost good faith, therefore, is that of avoidance of the contract ab initio under $\mathrm{s} 17$. This is a severe remedy that has retrospective effect and no right to damages. See also s 14 of the Insurance Act, 2015, which changes the consequence of non-compliance with the duty of utmost good faith. 
duty) $\cdot{ }^{40}$ Regarding good faith as a continuing duty, Hirst J in Black King Shipping $v$ Massie (The Litsion Pride) ${ }^{41}$ remarked that a post-contractual duty of good faith clearly existed between both the insurer and the policyholder. ${ }^{42}$ There is a marked difference between English law, where a continuing duty of good faith exists, and South African law, where the duty of good faith only exists during the precontractual stage. In English law, the continuous duty of good faith entails that the policyholder should not make any untrue statements or misrepresentations during the pre-contractual stage and that the parties should generally act with good faith towards one another during the contract. ${ }^{43}$ More specifically, prior to the contract being concluded, utmost good faith mainly comprises the policyholder's duty to disclose and not misrepresent all material facts to the insurer. ${ }^{44}$ The postcontractual position means that the policyholder must act honestly when making any claim under the policy. ${ }^{45}$

If one party breached the duty of utmost good faith, the only remedy under the MIA was for the other party to avoid the contract in its entirety, in other words, treat the policy as if it never existed. ${ }^{46}$ This remedy was much criticised. ${ }^{47}$

40 London Assurance Co v Mansel (1897) 11 Ch D 363367 and Birds, Lynch and Milnes (n 39) 453. However, the application of the post-contractual duty of good faith requires consideration of why the insurer is avoiding the contract, ie whether the insurer's decision to avoid the policy had been made in breach of good faith or whether the insurer's conduct involving claims handling amounts to a breach - in other words, whether the claim is a fraudulent one.

41 [1985] 1 Lloyd's Rep 437.

42 The Litsion Pride case, however, was subsequently overruled by Versloot Dredging BV v HDI Gerling Industrie Versicherung AG [2016] UKSC 45; [2016] WLR (D) 403 (appeal from [2014] EWCA Civ 1349).

43 Birds, Lynch and Milnes (n 39) 453-454.

44 s 17 of the MIA.

45 ibid.

46 ibid.

47 Lowry (n 14) 150. 


\section{The duty of disclosure}

Section 18 of the MIA deals with pre-contractual disclosures ${ }^{48}$ The central element of section 18 is that it places an onerous duty on the insured (the policyholder) to disclose to the insurer "every material circumstance" which the policyholder "knows or ought to know" before concluding a contract. ${ }^{49}$ Under section 18(2), a material circumstance is defined as "every circumstance which would influence the judgment of a prudent insurer in fixing the premium, or determining whether he will take the risk". ${ }^{50}$

This section effectively required the policyholder to look into the mind of a hypothetical sensible insurer and to work out what exactly would influence it, with little additional guidance by the insurers. ${ }^{51}$ Through an analysis of section 18 , it is suggested that the insurer plays a relatively passive role, without asking questions or indicating what it wishes to know. ${ }^{52}$ As a result, this led to policyholders burdening the insurers with large amounts of unnecessary information in an attempt to ensure that nothing was omitted..$^{53}$

Section 20(1) of the MIA provides for the issue of misrepresentations and stipulates that

48 S 18 provides as follows: "The assured must disclose to the insurer, before the contract is concluded, every material circumstance which is known to the assured, and the assured is deemed to know every circumstance which, in the ordinary course of business, ought to be known by him. If the assured fails to make such disclosure, the insurer may avoid the contract". See also Ivamy (n 37) 26.

49 Manifest Shipping Co Ltd v Uni-Polaris Insurance Co Ltd (The Star Sea) [2001] UKHL 1, [2003] 1 AC 469 (per Lord Hobhouse) par 54. See also Law Commission (n 36) par 3.7 and 3.8.

50 In Pan Atlantic Insurance Co Ltd v Pine Top Insurance Co Ltd [1995] 1 AC 501, the House of Lords confirmed that a material circumstance is one that would have an effect on the mind of the prudent insurer in assessing the risk. It is not necessary that it would have a decisive effect on the insurer's acceptance of the risk or on the amount of premium charged.

51 Pan Atlantic Insurance Co Ltd v Pine Top Insurance Co Ltd [1995] 1 AC 501 508. See also Lishman v Northern Maritime (1875) LR 10 CP 179. Section 18(3) deals with the exceptions to the duty to disclose: "Unless the insurer makes an enquiry, - an insured need not disclose: (a) any circumstance which diminishes the risk; (b) any circumstance which is known or presumed to be known to the insurer. The insurer is presumed to know matters of common notoriety or knowledge, and matters which an insurer in the ordinary course of his business, as such, ought to know; (c) any circumstance as to which information is waived by the insurer; and (d) any circumstance which it is superfluous to disclose by reason of any express or implied warranty".

52 ibid. See also Issues Paper 1: Misrepresentation and Non-Disclosure (September 2006) http://lawcommission. justice.gov.uk/docs/ICL1_Misrepresentation_and_Non-disclosure.pdf and http://www.scotlawcom.gov.uk/index. php/download_file/view/214/107/(02-02-2018).

53 ibid. Note that s 19 made the matter even more complicated by placing a stand-alone duty of disclosure on the policyholder's broker or any other agent, although the insurer's remedy for breach is against the policyholder. 
"[e]very material representation made by the assured or his agent to the insurer during the negotiations for the contract, and before the contract is concluded, must be true. If it be untrue the insurer may avoid the contract". ${ }^{54}$

The definition of a material representation in section 20(2) repeats the test for "material circumstances" in section 18(2) ${ }^{55}$ Section 20(3) of the MIA provides that "a representation may be either a representation as to a matter of fact, or as to a matter of expectation or belief".

The MIA provided only one remedy for the insurer in the case of misrepresentations and non-disclosures, namely avoidance of the contract. ${ }^{56}$ In other words, the contract is treated as if it has never been made and all claims made under it are refused..$^{57}$ Avoidance of the contract normally required restitution, meaning that the parties must be restored to the positions they were in prior to the contract being made, except where one was guilty of fraud..$^{58}$

\section{Criticism}

By way of summary, it may be stated that the duty of disclosure in terms of the MIA was excessively wide. ${ }^{59}$ The policyholder was under a burden to disclose "every material circumstance" which might be relevant to an insurer, while the insurer was able to play a relatively passive role. This was an unfair practice, placing the already vulnerable policyholder in a detrimental position. ${ }^{60}$ These problems were further exacerbated by the fact that the only remedy for non-disclosure was avoidance of the contract.

54 Economides v Commercial Union Assurance Co Plc [1998] QB 587593.

55 In that it must influence the judgment of a prudent insurer in fixing the premium or deciding whether to take on the risk.

56 s 17 of the MIA.

57 ibid.

58 Regarding marine insurance, s 84(3)(a) of the MIA provides as follows: "Where the policy is void, or is avoided by the insurer as from the commencement of the risk, the premium is returnable, provided that there has been no fraud or illegality on the part of the assured".

59 Tyldesley “Consumer insurance law - reform at last?” 2010 Amicus Curiae 13.

60 Tyldesley "Insurance law - unfair, unclear, archaic and inaccessible?” 2006 Amicus Curiae 1. 
Judges were not silent in expressing their unease over the rigours of the disclosure duty in terms of sections 17 and 18 of the MIA. ${ }^{61}$ In Anglo-African Merchants Ltd $v$ Bayley, ${ }^{62}$ Megaw J queried whether the insured should be bound to disclose that which he does not appreciate to be material. ${ }^{63}$ In Lambert $v$ Cooperative Insurance Society $L t d,{ }^{64}$ all three judges in the Court of Appeal took the opportunity to criticise the prudent insurer test. ${ }^{65}$ At the time, the judges even called for parliamentary intervention to address the inequalities caused by the severity of the duty. ${ }^{66}$ With respect to the insurer's right of avoidance in terms of the duty, the judiciary also condemned the results which flowed from exercising the remedy ${ }^{67}$ In Kausar v Eagle Star Insurance Co Ltd, ${ }^{68}$ Staughton LJ stated:

\begin{abstract}
"Avoidance for non-disclosure is a drastic remedy. It enables the insurer to disclaim liability after, and not before, he has discovered that the risk turns out to be a bad one; it leaves the insured without the protection which he thought he had contracted and paid for...I do consider there should be some restraint in the operation of the doctrine. Avoidance for honest non-disclosure should be confined to plain cases". ${ }^{69}$
\end{abstract}

The "all-or-nothing" avoidance rule of section 17 was viewed as largely "disproportionate".$^{70}$ This was due to the fact that no matter the type of breach and whether it occurred at the pre-or post-contractual stage, avoidance was the sole remedy. ${ }^{71}$ However, this distinction is of less importance today following the amendment to section 17 of the MIA brought about by section 14 of the Insurance Act, 2015. ${ }^{72}$

\footnotetext{
61 Lowry (n 14) 115-116.

62 [1970] 1 QB 311.

63 ibid 319.

64 [1975] 2 Lloyd's Rep 485 (AC).

65 ibid 491-493.

66 ibid.

67 Lowry (n 14) 117.

68 [1997] CLC 129.

69 ibid 132-33.

70 Birds, Lynch and Milnes (n 39) 453-454 and Lowry (n 14) 117-118.

71 ibid.

72 Thanasegaran Good Faith in Insurance and Takaful Contracts in Malaysia (2016) 17. S 14 of the 2015 Insurance Act provides that insurance contracts are still contracts of utmost good faith, however, "any rule of law permitting a party to a contract of insurance to avoid the contract on the ground that the utmost good faith has not been observed by the other party, is abolished".
} 


\section{The need for legislative reform}

In 1978, the Law Commission was given the opportunity to review nondisclosure. ${ }^{73}$ The recommendations put forward by the Commission included a noticeably revised duty of disclosure that, had it been implemented, would have resulted in moving the focus away from the "prudent insurer" as the decisive test of materiality. ${ }^{74}$

The Commission proposed a reformed duty of disclosure for both consumers and businesses. ${ }^{75}$ This modified duty would require an insured to disclose those facts that a reasonable person in the position of the applicant would disclose. ${ }^{76}$ Notwithstanding the fact that many were optimistic that such legislative reform would take place, this slowly faded out over time. ${ }^{77}$

It was only after the 2006 Law Commission enquiry that change eventually occurred. ${ }^{78}$ This resulted in the culmination of a few new statutes, namely the Consumer Insurance (Disclosures and Representations) Act, 2012 (applicable to consumer contracts), the Consumer Rights Act, 2015, and the Insurance Act, 2015.

The sections on disclosures and utmost good faith, as highlighted above, have since undergone reform in terms of the Insurance Act, $2015 .{ }^{79}$ The statutory reforms to the duty of utmost good faith as introduced in this Act will be discussed below. The duty of fair presentation as introduced in this Act has also had an effect on the duty of utmost good faith, as will be seen in paragraph 3 below.

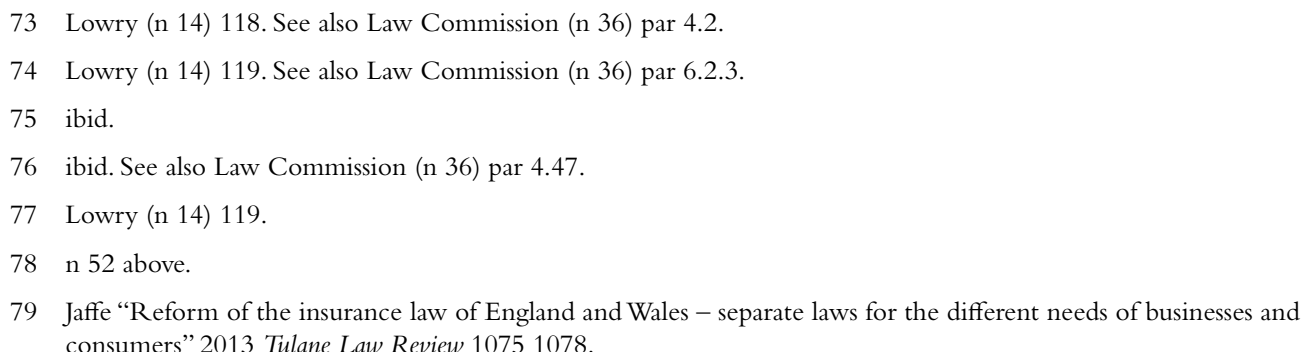




\section{THE INSURANCE ACT 2015}

\section{Introduction}

The newly enacted Insurance Act, 2015, seeks to strike a fairer balance between policyholders and insurers. ${ }^{80}$ The Act creates new duties for both the insurer and policyholders ${ }^{81}$ and regulates the duty of disclosure, both before a contract comes into being and when such contract is amended. ${ }^{82}$ The Act also addresses warranties (including the basis-of-contract clauses), terms not relevant to the actual loss, fraudulent claims by an insured party and good faith. It also amends some provisions of the Third Parties (Rights Against Insurers) Act, 2010.

The Act does not anticipate to be a full codification of insurance laws and, alongside it, other laws on insurance law will continue to apply, such as the Marine Insurance Act, 1906, and the Third Parties (Rights Against Insurers) Act, 2010. ${ }^{83}$ The Act applies in England, Wales, Scotland and Northern Ireland. ${ }^{84}$ The new law, rather than being a strict code, sets out principles to be followed, with the aim of being adequately flexible to cater for from the smallest business to major corporations. ${ }^{85}$

The new duty of fair presentation and the new effect of a breach of the duty of good faith apply only in relation to contracts of insurance entered into on or after 12 August 2016 and to variations agreed to on or after 12 August 2016 in respect of contracts agreed at any time. ${ }^{86}$

80 Merkin and Gurses “The Insurance Act 2015: Rebalancing the interests of the insurer and the assured” 2015 Modern Law Review 10041008.

81 ibid.

82 See Hertzell and Burgoyne "The Law Commissions and insurance contract law reform: An update" 2013 Journal of International Maritime Law (JIML) 105110.

83 This Act is aimed at protecting a claimant who has a claim against an insolvent, but insured defendant by transferring the insured's rights under the insurance policy to the third party and enabling the latter to proceed against the insurer. See also Soyer "Insurance Act 2015 coming into force: Overhauling commercial insurance law in the UK" 2016 JIML 253256.

84 See Hertzell and Burgoyne (n 82) 123.

85 ibid; Soyer (n 83) 253 254. It is important to note that the Act will not apply retrospectively. See Merkin and Gurses (n 80) 1004-1027.

86 ibid. The new law on warranties, terms not relevant to the actual loss and fraudulent claims will apply only in relation to contracts of insurance entered into on or after 12 August 2016, and to variations of such contracts. See Merkin and Gurses (n 80) 1027. 
In this Act, ${ }^{87}$ the concept of "consumer insurance contract" has the same meaning as in the Consumer Insurance (Disclosure and Representations) Act, 2012. The term "non-consumer insurance contract" means a contract of insurance that is not a consumer insurance contract.

\section{The duty of fair presentation}

Starting with the legislation, section 2 of the Act sets out the application and interpretation of the new duty of fair presentation. It stipulates that this duty applies to non-consumer contracts and the variation thereof. ${ }^{88}$

Section 3 defines what is meant by the duty of fair presentation. Before a contract of insurance is entered into, the insured must make a fair presentation of the risk to the insurer. ${ }^{89}$ Subsection 2 states that the duty imposed by subsection 1 is referred to in the Act as "the duty of fair presentation". A fair presentation of the risk is described in subsection 3 as one which makes the disclosure required by subsection $4 .{ }^{90}$ In addition, the representation or the disclosure must be made in a manner which would be reasonably clear and accessible to a prudent and in such a manner that "every material representation as to a matter of fact is substantially correct, and every material representation as to a matter of expectation or belief is made in good faith". ${ }^{91}$

Section 4 sets out what constitutes knowledge of the policyholder and stipulates that a policyholder is an individual who knows only what is actually known to him or her or what is known to one or more individuals who are

87 apart from Part 6.

88 Subs 2 provides that "this Part applies in relation to variations of non-consumer insurance contracts as it applies to contracts, but (a) references to the risk are to be read as references to changes in the risk relevant to the proposed variation, and (b) references to the contract of insurance are to the variation". A non-consumer insurance contract "means a contract of insurance that is not a consumer insurance contract". See the Insurance Act, 2015.

89 s 1 of the Act.

90 S 4 reads as follows: "The disclosure required is as follows, except as provided in subsection (5) - (a) disclosure of every material circumstance which the insured knows or ought to know, or (b) failing that, disclosure which gives the insurer sufficient information to put a prudent insurer on notice that it needs to make further enquiries for the purpose of revealing those material circumstances".

91 s 3(3)(b)-(c) of the Act. S 3(5) goes on to provide for the following: "In the absence of enquiry, subsection (4) does not require the insured to disclose a circumstance if (a) it diminishes the risk, (b) the insurer knows it, (c) the insurer ought to know it, (d) the insurer is presumed to know it or (e) it is something as to which the insurer waives information". 
responsible for the policyholder's insurance. ${ }^{92}$ Subsection 3 goes on to provide that a policyholder "who is not an individual knows only what is known to one or more of the individuals who are (a) part of the insured's senior management, or (b) responsible for the insured's insurance". ${ }^{93}$

What is significant about this statute is that disclosure of knowledge under the MIA used to be a duty that was placed on the prospective policyholder. The important shift that took place to a shared responsibility between policyholders and insurers is evident from section 5 , which describes what is meant by the knowledge of the insurer:

"(1) For the purposes of section 3(5)(b), an insurer knows something only if it is known to one or more of the individuals who participate on behalf of the insurer in the decision whether to take the risk, and if so on what terms (whether the individual does so as the insurer's employee or agent, as an employee of the insurer's agent or in any other capacity).

(2) For the purposes of section 3(5)(c), an insurer ought to know something only if-

(a) an employee or agent of the insurer knows it, and ought reasonably to have passed on the relevant information to an individual mentioned in subsection (1), or

(b) the relevant information is held by the insurer and is readily available to an individual mentioned in subsection (1).

(3) For the purposes of section 3(5)(d), an insurer is presumed to know-

(a) things which are common knowledge, and

(b) things which an insurer offering insurance of the class in question to insureds

92 s 4(2) of the Act.

93 Subsequent relevant subsections of s 4 provide as follows: “(4) An insured is not by virtue of subsection (2)(b) or (3)

(b) taken to know confidential information known to an individual if - (a) the individual is, or is an employee of, the insured's agent; and (b) the information was acquired by the insured's agent (or by an employee of that agent) through a business relationship with a person who is not connected with the contract of insurance. (5) For the purposes of subsection (4) the persons connected with a contract of insurance are- (a) the insured and any other persons for whom cover is provided by the contract, and (b) if the contract re-insures risks covered by another contract, the persons who are (by virtue of this subsection) connected with that other contract. (6) Whether an individual or not, a policyholder ought to know what should reasonably have been revealed by a reasonable search of information available to the policyholder (such search may be conducted by making enquiries or by any other means). (7) In subsection (6) 'information' includes information held within the insured's organ or by any other person (such as the insured's agent or a person for whom cover is provided by the contract of insurance)". See subsection 8 for definitions. 
in the field of activity in question would reasonably be expected to know in the ordinary course of business".

Remedies for breach of the duty of fair presentation have been set out in section 8 and are far more proportionate than the previous regime of avoidance. ${ }^{94}$

To summarise these provisions, the potential policyholder is now under an obligation to disclose everything that is known to him or her, or which should be known to him or her, which will affect the insurer's decision of whether to accept the risk or not. In addition to this, the potential policyholder must also draw the attention of the insurer to all information which is relevant to the insurance coverage. ${ }^{95}$ The policyholder, however, is not obliged to disclose matters already known to the insurer and insurers are required to mention from the start those matters which, in their opinion, are needed for the purposes of accepting the insurance. ${ }^{96}$

\section{Evaluation of the duty of fair presentation}

Through the inclusion of the duty of fair presentation, the Act aims to encourage co-operation between the policyholder and the insurer at a precontractual stage. ${ }^{97}$ The aim of co-operation is reached by introducing a new

94 S 8 reads as follows: "(1) The insurer has a remedy against the insured for a breach of the duty of fair presentation only if the insurer shows that, but for the breach, the insurer - (a) would not have entered into the contract of insurance at all, or (b) would have done so only on different terms. (2) The remedies are set out in Schedule 1. (3) A breach for which the insurer has a remedy against the insured is referred to in this Act as a 'qualifying breach'. (4) A qualifying breach is either- (a) deliberate or reckless, or (b) neither deliberate nor reckless. (5) A qualifying breach is deliberate or reckless if the insured- (a) knew that it was in breach of the duty of fair presentation, or (b) did not care whether or not it was in breach of that duty. (6) It is for the insurer to show that a qualifying breach was deliberate or reckless".

95 S 3(4)(a)-(b) of the Act provides as follows: "Insured parties will be considered to have known, or ought to have known: matters that could be expected to be revealed by a reasonable search of information available to the insured party - for example, information held within an organisation or by a broker; anything known by a person responsible for their insurance - for example, a broker; insured organisations will also be deemed to have the knowledge of anyone who is a part of the organisation's senior management, or who is responsible for their insurance".

96 S 3(5) and (6) of the Act reads: "Insurers will be considered to have known, or ought to have known: matters known to individuals who participate on behalf of the insurer in deciding whether to take the risk and on what terms - for example, underwriting teams; knowledge held by the insurer and readily available to the person deciding whether to take the risk; and matters known by an employee or agent of the insurer and which should reasonably have been passed on to the person deciding whether to take the risk". Brokers will no longer be subjected to the old disclosure duties to which they were subjected previously. See also Thomas "The Insurance Act 2015 - a new duty of "fair presentation"” 2016 Company Secretary's Review 449.

Birds, Lynch and Milnes (n 39) 575. 
obligation on a policyholder to make a fair presentation of the risk to the insurer. ${ }^{98}$ This presentation should disclose all the information in a reasonably clear and understandable manner. ${ }^{99}$ In addition, the policyholder must ensure that every material representation as to a matter of fact is substantively correct and that every material representation as to a matter of belief or expectation is made in good faith. ${ }^{100}$

Before the Insurance Act, 2015, came into operation, potential policyholders were required to disclose every circumstance that they knew, or ought to have known, would influence an insurer in fixing a premium or deciding whether to underwrite a risk. ${ }^{101}$ This generally required policyholders to predict, without much guidance from the insurer, by what factors a hypothetical insurer would be influenced. ${ }^{102}$ This burden on the policyholder was somewhat cumbersome. The new Act ${ }^{103}$ has created a fairer "duty of fair presentation" aimed at encouraging active, rather than passive, engagement by insurers as well as clarifying and specifying known or presumed to be known matters. ${ }^{104}$

The new obligation of fair presentation has a number of practical implications for both the policyholder and the insurer. Pre-disclosure analysis by the policyholder and sifting of all relevant information will be needed to ensure that disclosure is made in a reasonably clear and understandable manner. ${ }^{105}$ If the policyholder does make a misrepresentation, the insurer is entitled to the

98 Under the Act, a policyholder is required to disclose every material circumstance which the policyholder knows or ought to know, and to conduct a reasonable search of its records to discharge the duty of fair presentation. See Birds, Lynch and Milnes (n 39) 575.

99 "Data dumping" is therefore no longer permissible.

100 s 3(4). See also Thomas (n 96) 49.

101 Birds, Lynch and Milnes (n 39) 575. Take note that the Consumer Insurance (Disclosures and Representations) Act, 2012, also changed the dispensation under the MIA.

102 The same obligation extended to brokers acting on behalf of policyholders. See Birds, Lynch and Milnes (n 39 ) 575. See also Law Commissions Report (n 36) par 6.2.

103 in Part 2.

104 The policyholder, before entering into a contract of insurance, will be required to disclose either: every matter which they know, or ought to know, that would influence the judgement of an insurer in deciding whether to insure the risk and on what terms; or sufficient information to put an insurer on notice that it needs to make further enquiries about potentially material circumstances. See Birds, Lynch and Milnes (n 39) 575.

105 Under the Act, disclosure must be made in a reasonably clear and accessible manner, material representations of fact must be "substantially correct" and material representations of expectation or belief must be made in "good faith". Individuals will be deemed to know matters which they suspected and which they would have known about had they not deliberately refrained from confirming or enquiring about them. 
proportionate remedies as highlighted in section 8 , depending on the type of breach committed by the policyholder.

As indicated, insurers will no longer be able to rely on a passive approach to disclosure. ${ }^{106}$ More active engagement is encouraged and, if not in place already, insurers should consider establishing systems and processes to identify when further enquiries need to be made before underwriting risks. ${ }^{107}$ Insurers must review what information is readily available to those who decide whether to accept risks and the terms on which to do so. ${ }^{108}$

Section 8 of the Insurance Act (mentioned above) sets out the remedies for the insurer in case of breach of the duty of fair presentation by the policyholder. This section stipulates that if the policyholder is in breach of the duty of fair presentation, either deliberately or recklessly, the insurer can avoid the policy and keep all premiums paid. ${ }^{109}$ In the situation where the policyholder's breach is not deliberate or reckless, the insurer can avoid the policy and return all premiums paid, provided that the insurer can prove that it would not have entered into the policy at all. If the insurer would have entered into the policy on different terms, the policy will be treated as if it included those terms. Lastly, if the insurer would have entered into the contract but would have charged the policyholder a higher

106 Birds, Lynch and Milnes (n 39) 575 and Law Commission (n 33) par 6.2. In South Africa, this has also been a problem. The court in Mahadeo v Dial Direct Insurance Ltd [2008] JOL 21383 (W) stated that insurers must ask the correct questions in order to determine the risk because they have a notion of the kind of information they require. The duty of fair presentation in English law clearly takes cognisance of this thorny issue. In South Africa, the General Code of Conduct (GCC) adopted in terms of the FAIS Act has detailed rules on the pre-contractual duties of insurers when selling products. See s 7 of the FAIS GCC. These stipulations are supplemented by rule 11.3.4 of the 2018 Policyholder Protection Rules (PPRs): "Information provided must enable a policyholder to understand the features of the policy and help the policyholder understand whether it meets the policyholder's requirements. In determining the level of information to be disclosed the insurer must consider (a) the factually established or reasonably assumed knowledge and experience of the policyholder or average targeted policyholder at whom the communication is targeted; (b) the policy terms and conditions, including its main benefits, exclusions, limitations, conditions and its duration; (c) the policy's overall complexity, including whether it is entered into together with other goods and services; and (d) whether the same information has been provided to the policyholder previously and if so, when". It is evident that there is a growing trend in both England and South Africa to compel insurers to take a more active role in determining the risk and in assisting prospective policyholders in disclosing the correct information.

107 Law Commission (n 36) par 6.2. See also Thomas (n 96) 49.

108 Insurers should consider keeping internal records of the names and roles of individuals responsible for these decisions and establish appropriate processes and lines of communication to ensure that relevant information is shared with other insurers.

109 s 8 of the Insurance Act, 2015. 
premium, the insurer may reduce proportionately the amount to be paid on a claim to reflect that premium adjustment. ${ }^{110}$

Previously, an insurer was able to refuse all claims under an insurance contract if the pre-contractual disclosure duty was breached, even if the breach was committed by the broker. ${ }^{111}$ The 2015 Act has now introduced a range of proportionate remedies, which are applied according to the type of breach committed. ${ }^{112}$ It is important to note that these proportionate remedies are much fairer.To bring an action for relief for non-disclosure, insurers will need to be able to prove how they would have acted differently if the breach had not occurred. ${ }^{113}$

\section{Good faith}

As was stated in paragraph 2.1, in terms of section 17 of the MIA of insurance were based on utmost good faith and, if the policyholder breached this duty, the insurer could avoid the contract in its entirety. ${ }^{114}$ In terms of section 14 of the 2015 Act, no party may now avoid the contract based on the ground that the duty of utmost good faith has not been complied with. ${ }^{115}$ Section 14 deals with good faith and reads as follows:

“(1) Any rule of law permitting a party to a contract of insurance to avoid the contract on the ground that the utmost good faith has not been observed by the other party is abolished.

(2) Any rule of law to the effect that a contract of insurance is a contract based on the utmost good faith is modified to the extent required by the provisions of this Act and the Consumer Insurance (Disclosure and Representations) Act 2012.

110 ibid.

111 Birds, Lynch and Milnes (n 39) 588-589 and Law Commission (n 36) par 11.37.

112 ibid.

113 Birds, Lynch and Milnes (n 39) 589. See also Law Commission (n 36) par 11.44-11.46. Disclosure of underwriting guides and other relevant documents may now be required, along with records of underwriting decisions made and factors considered in particular cases. The link between pre-contractual presentations and fraud is that all failures to disclose are intentional or even remotely fraudulent. However, if parties are confronted with a situation where precontractual misstatements may perhaps be fraudulent, the law is now just and clear.

114 See the South African position on good faith which stemmed from the decision in Mutual and Federal Co Ltd $v$ Oudtshoorn Municipality 19851 SA 419 (A).

115 s 14(1). 
(3) Accordingly-

(a) in section 17 of the Marine Insurance Act 1906 (marine insurance contracts are contracts of the utmost good faith), the words from ", and" to the end are omitted, and

(b) the application of that section (as so amended) is subject to the provisions of this Act and the Consumer Insurance (Disclosure and Representations) Act 2012.

(4) In section 2 of the Consumer Insurance (Disclosure and Representations) Act 2012 (disclosure and representations before contract or variation), subsection (5) is omitted".

It is thus clear that section 14 does not repeal section 17 of the MIA in its entirety. Rather, section 14 repeals only the part of section 17 which states that the insurer may avoid the contract in its entirety if the duty of utmost good faith has not been complied with. This means that contracts of insurance are still based on utmost good faith and this concept still plays a significant role in a contract of insurance. The duty of fair presentation coincides with the duty of utmost good faith as both duties essentially require that policyholders not make any misrepresentations to the insurer.

\section{Evaluation of good faith}

Before the enactment of the 2015 Act, either party could avoid the insurance contract if the other failed to act in accordance with "utmost good faith". ${ }^{116}$ Part 5 of the Act has now removed avoidance of contract as a remedy for breach of this duty and abolished any parts of legislation prescribing this as a remedy. ${ }^{117}$ Insurance contracts will still be based on utmost good faith and clauses and obligations will be interpreted in a way that favours compliance with this duty. ${ }^{118}$ In a sense, the Act aligns the English position with the South African position. It brings about a fairer dispensation in that avoidance is no longer permissible and more equitable remedies are to be sought.

116 See the South African position as laid out in the Oudtshoorn Municipality case (n 1).

117 s 14 of the Insurance Act. See also Birds, Lynch and Milnes (n 39) 591.

118 s 14 of the Insurance Act. See also Axa General Insurance Ltd v Clara Gottlieb and Joseph Meyer Gottlieb [2005] EWCA Civ 112 (CA). 


\section{HAS THE DUTY OF UTMOST GOOD FAITH STOOD THE TEST OF TIME?}

What is evident from the above discussion on utmost good faith is that English law still seems very much "married" to this concept. The fact that the 2015 Act still refers to this concept shows a reluctance to move away from what has been conceptualised ages ago and may very well be out of pace with modern insurance business practices. When Carter insured Fort Marlborough, Boehm had no way of knowing whether the fort would hold against enemy attack and Boehm had no choice but to rely on Carter's word. It is no wonder then that good faith in this context found its way into legislation and that the remedy under the original 1906 Act was avoidance of the contract. Insurers needed to be protected due to the general asymmetry of information that existed between the insurer and the insured. During the 1800 s, communications were slow and unreliable. It was virtually impossible for the insurer to inspect the subject-matter being insured or the scene of the risk. Modern-day insurance contracts are concluded on a different basis and underwriters have other methods at their disposal (such as detailed statistical data) with which to calculate risk. This is why it is not surprising that the remedy of avoidance was repealed by the 2015 Act. ${ }^{119}$ The old remedy was always held to be controversial and led to unfair results. ${ }^{120}$ Now, a fairer dispensation is observed. No longer is avoidance of the contract the sole remedy for breach of the duty of disclosure. Therefore, although contracts of insurance are still recognised as contracts of utmost good faith, it seems that the concept of utmost good faith is being transformed into something more fair and equitable for both the insurer and the insured.

The introduction of the duty of fair presentation has also led to the repeal of sections 18 and 20 of the MIA and the fact that the 2015 Act has introduced a fairer dispensation involving a duty of "fair presentation" shows that the duty of utmost good faith no longer serves its original purpose. One may therefore conclude that the duty of utmost good faith no longer serves the original purpose as envisaged by Lord Mansfield when he introduced the duty of disclosure in

119 s 15 of the Insurance Act, 2015.

120 Lowry (n 14) 150. 
the eighteenth and nineteenth centuries. ${ }^{121}$ The previous dispensation relating to disclosure was undoubtedly necessary during that period when the context was mainly marine. The insured was generally in a much better position with regard to knowledge of the risk and utmost good faith, in this context, served a purpose. It stands to reason that, as the asymmetry of information relative to a particular transaction being negotiated is less significant, utmost good faith similarly became less significant. That is why the duty to disclose, together with the remedies for non-disclosure, needed to be reformed. This deficiency is capable of being treated by requiring the insurer to ask specific questions, which is in fact now the case with the duty of fair presentation. ${ }^{122}$ Consequently, it is no longer the sole duty of the policyholder to burden the insurer with unnecessary information. Insurers now play a more active role in establishing the risk to be insured and the duty of utmost good faith does not seem to serve its original purpose as set out in the nineteenth century.

In conclusion, what remains of utmost good faith is only the shell and, thankfully, its content is more equitable and leads to a fairer dispensation.

\section{GOOD FAITH IN MARINE INSURANCE LAW IN SOUTH AFRICA}

\section{Legislative and conceptual framework}

South African marine insurance can be traced back to the lex mercatoria and, therefore, has the same roots as English insurance law. ${ }^{123}$ As marine insurance inevitably has an international character, comparisons between jurisdictions often show that standard insurance practices, such as subrogation and salvage, apply across the board. As was alluded to in paragraph one above, English law is not a source of South African law as such, but it does have persuasive authority. ${ }^{124}$

121 Carter case (n 12).

122 See the discussion above on the duty of fair presentation.

123 Reinecke et al (n 8) 19.

124 Oudtshoorn Municipality case (n 1). 
As in England, insurance in South Africa is often classified in order to refer to the kind of cover offered by a specific kind of insurance. ${ }^{125}$ It is therefore common to refer to motor insurance, life insurance, aviation insurance and marine insurance, to name but a few. ${ }^{126}$ In this case, the insurance is classified according to the so-called "line" of cover provided by the particular insurance contract. Reinecke, Van Niekerk and Nienaber are of the opinion that, in most instances, differentiations are retained "for the sake of habit" and not because different principles are applied to these different types of contracts. ${ }^{127}$ This is, of course, correct. It must be stated, however, that, in South Africa, licensing requirements often inform decisions to categorise insurance business. To that end, two statutes have for some time distinguished between life insurance and non-life insurance.The Long-term Insurance Act (LTIA) ${ }^{128}$ and the Short-term Insurance Act (STIA) ${ }^{129}$ have contained rules pertaining to life and non-life insurance respectively and these two statutes contain very similar stipulations. Marine insurance as a line of business was regulated by the STIA.

On 1 July 2018, the Insurance Act (IA) ${ }^{130}$ came into operation. This statute is of significance for the remainder of the discussion because it repealed key sections of the LTIA and STIA. In addition, the IA abolishes the concepts "longterm insurance" and "short-term insurance" and, henceforth, uses life and non-life insurance, thereby developing the South African conceptual framework in line with international standards. The IA classifies marine insurance as category 5 , subcategory a) being "personal lines" and b) "commercial lines". ${ }^{131}$ The Act stipulates that these two classes of marine insurance cover "damage or loss resulting from the possession, use or ownership of vessels used on or in a river, canal, dam, lake or sea". Category 10(a) further provides for liability (marine) insurance, denoting liability to another person caused by marine risks. This distinction between property and

125 Reinecke et al (n 8) 10 .

126 ibid.

127 ibid.

12852 of 1998.

12953 of 1998.

13018 of 2017.

131 See table 2 of the IA, which contains classes and sub-classes of insurance. 
liability insurance is also made for a number of other types of niche insurance, such as aviation and rail insurance. The purpose of this contribution, however, is to evaluate the concept of good faith and to compare this aspect of marine insurance as it is currently applied in the two jurisdictions in question.

\section{Good faith in South African insurance contracts}

One of the two main differences between English insurance law and South African insurance law is that the concept of utmost good faith is still used in England regardless of the fact that the meaning of utmost good faith has changed from the MIA to the current statutory framework. In South Africa, it has been emphatically stated that there is no such thing as utmost good faith, but rather that insurance contracts, like any other contracts in South Africa, are contracts in good faith. ${ }^{132}$ The second difference is that the duty of good faith in South Africa has always been a pre-contractual duty. ${ }^{133}$ In England, however, the same duty does not only exist at the pre-contractual stage, but continues for the duration of the contract. This means that it is generally expected that the duty of utmost good faith be observed throughout the continued existence of the contract. This is clearly different from the South African purely pre-contractual duty.

It is important to keep in mind that the duty of good faith in relation to the duty of disclosure resting on a prospective policyholder pertains to the fact that an insurer must be in a position to quantify the possibility of loss "to a degree of probability", based on facts disclosed by the prospective policyholder. ${ }^{134}$ The insurer, therefore, requires information about all the facts that will affect the risk. It is only then that the insurer can calculate the risk, decide whether or not to insure the risk and, ultimately, impose restrictions on the insured amount and other conditions and exclusions in the contract.

It is therefore predominantly in the pre-contractual phase that good faith plays a very important role.This exposition of South African law on good faith will,

132 Oudtshoorn Municipality case (n 1). See Reinecke and Becker "Die openbaringsplig by versekering: Uberrima fides oorboord: Mutual and Federal Insurance Co Ltd v Oudtshoorn Municipality” 1985 TSAR 8688.

133 Reinecke et al (n 8) 140.

134 ibid 142. 
however, argue that the role of good faith in insurance law has changed somewhat over the past two decades, mainly because of three events, namely the introduction of the FAIS Act, the promulgation of the PPRs and the most recent promulgation of the Insurance Act. ${ }^{135}$ As a result, it is submitted that marine insurance as a form of non-life insurance is currently subject to exactly the same rules pertaining to good faith and misrepresentation as any other form of non-life insurance.

However, before the FAIS Act is discussed, it is necessary to provide a brief overview of good faith and misrepresentation in South Africa.

\section{Good faith and misrepresentation}

Generally speaking, misrepresentation has the effect of influencing consensus. ${ }^{136}$ South African law regards culpable misrepresentation as a wrongful act or a delict. ${ }^{137}$ Misrepresentation may be by way of an omission (non-disclosure) or positive conduct and, furthermore, non-disclosure of certain facts entails a failure to speak where there is a duty to speak, while a misrepresentation by positive conduct takes place if a prospective policyholder creates by his conduct a wrong impression relating to a fact. ${ }^{138}$ When further classifying misrepresentations, a distinction is made between innocent, negligent and intentional misrepresentations. ${ }^{139}$ Innocent misrepresentations occur when a reasonable person in the position of the insured would not have realised that the statement was untrue or that it would harm the insurer. ${ }^{140}$ Intentional misrepresentation is where the person making the disclosure is aware of the fact that the statement is incorrect. ${ }^{141}$ Negligent misrepresentation occurs where the insured does not realise that his statement is untrue or that it would harm the insurer, while a reasonable person would have realised this and

\footnotetext{
13518 of 2017.
}

136 Prozesky-Kuschke "Specific aspects of insurance contracts and indemnity and non-indemnity insurance" in Nagel (ed) Commercial Law (2015) 367.

137 Reinecke "Remedies for misrepresentation inducing a long-term insurance contract: The Didcott principle" 2009 SA Merc LJ 387-395.

138 ibid.

139 Millard Modern Insurance Law in South Africa (2013) 72.

140 Reinecke (n 137) 388.

141 ibid. 
would also have foreseen it. ${ }^{142}$ In the context of insurance, it is the prospective policyholder who bears the duty of disclosing to the insurer certain information prior to the conclusion or the renewal of his insurance contract. ${ }^{143}$ During the pre-contractual stage, parties are still to negotiate the contract and this means that the duty to disclose cannot be a contractual one, which is why breach of this duty (misrepresentation) is a delict. ${ }^{144}$ More specifically, where the insured discloses the wrong information or fails to disclose essential, material information and where the insurer acts to his detriment by accepting a risk that has not been fully comprehended, these acts of the (then) prospective policyholder becomes actionable. Not all misrepresentations, however, are material to the risk. Generally speaking, a misrepresentation is material if: (a) it would have induced a reasonable person to contract in reliance on it; (b) it was reasonably likely to convince someone to contract; or (c) it has the probable effect of influencing the mind of the insurer. ${ }^{145}$ The common law position was, in fact, codified by section 59 of the LTIA and section 53 of the STIA, which contained the exact same wording. The essence of these sections was found in sub-sections 59(1)(b) and 53(1)(b), which stated that the misrepresentation or non-disclosure in question,

\begin{abstract}
"shall be regarded as material if a reasonable, prudent person would consider that the particular information constituting the representation or which was not disclosed, as the case may be, should have been correctly disclosed to the insurer so that the insurer could form its own view as to the effect of such information on the assessment of the relevant risk".
\end{abstract}

The effect of these sections was that an insurer could only exercise its contractual remedies if the misrepresentation or non-disclosure materially influenced the assessment of the risk under the policy at the time of its conclusion. This is the position even where the policyholder warranted that he had provided the correct

142 ibid.

143 Van Niekerk "The insured's duties of disclosure: delictual and contractual; before the conclusion and during the currency of the insurance contract: Bruwer v Nova Risk Partners Ltd” 2011 SA Merc LJ 135135.

144 Millard (n 139) 73; Reinecke et al (n 8) 136.

145 Nortje “A new look at materiality” 2012 TSAR 468. 
information, the only difference being that, because the warranty was breached, the misrepresentation or non-disclosure amounts to breach of contract. ${ }^{146}$

The essence of the issue remains the matter of good faith. As misrepresentation goes to the very heart of the agreement to take over the risk, the importance of this doctrine cannot be over-emphasised. Note that section 59 of the LTIA and section 53 of the STIA only pertained to the voidability of contracts in the instance of misrepresentations that could materially influence the assessment of the risk under the policy at the time of its conclusion. ${ }^{147}$ As was stated before, the IA repealed section 59 of the LTIA and section 53 of the STIA. This means that the common law position as it was before the enactment of these two sections is restored, namely that the insurer may repudiate a claim and cancel a contract if the misrepresentation was wrongful or, in other words, material to the risk. If a warranty was included in the contract in terms of which the insured warranted that all information was correct, the contract can be avoided based on breach of warranty, which is breach of contract. ${ }^{148}$ It is argued, however, that elements of the overall legislation currently conspire to create a legal dispensation where it is no longer possible simply to view misrepresentations and non-disclosures in such a narrow way. In essence, the FAIS Act and the PPRs contain rules that, when read together, indicate that insurance companies, as well as their agents and intermediaries, should play a more active role in establishing the true facts before offering insurance cover.

146 Reinecke et al (n 8) 159; Van Niekerk "Goodbye to the duty of disclosure in insurance law: reasons to rethink, restrict, reform or repeal the duty (part 2)” 2005 SA Merc LJ 323337.

147 Reinecke et al (n 8) 165-166.

148 Reinecke et al (n 8) 167. Breach of warranty per se, however, cannot simply warrant cancellation of the contract by the insurance company. Section 53(1)(a) of STIA provides that, if a representation that is the subject of a warranty turns out to be untrue, an insurer may only cancel the contract if the representation is "such as to be likely to have materially affected the assessment of the risk under the policy concerned at the time of its issue or at the time of any variation thereof". This measure brought some relief to policyholders in the wake of widely criticised cases such as Jordan v New Zealand Insurance Co Ltd 19682 SA 238 (E) and John v North British and Mercantile Insurance Co (1902) 19 SC 414, (1902) 12 CTR 771. Reinecke et al (n 8) 311 states that section 53(1)(a) does not provide sufficient protection to policyholders. It is submitted that the measures introduced by the IA for life insurance provide better protection and should also be introduced for non-life insurance. See the discussion in par 5.6 below. 


\section{Financial Advisory and Intermediary Services Act}

The FAIS Act was introduced to regulate the activities of all intermediaries and advisors who sell financial products. Because the statutory definition of "financial product" includes insurance, the entire Act applies to the insurance business. ${ }^{149}$ During the all-important phase where pre-contractual disclosures pertaining to the risk are made by prospective insurers, the FAIS Act and, more specifically, the General Code of Conduct (GCC) in terms of the Act contain stipulations that place a duty on insurance intermediaries and advisors to assist the prospective insured in disclosing information that is relevant to the risk. The GCC is a code under the FAIS Act and, because the FAIS Act is aimed mainly at market regulation, the GCC and other codes of conduct set minimum standards to which financial services providers' conduct must conform when dealing with clients. The obligation to assist the prospective insured to disclose information that is material to the risk is but one of the many obligations provided for by the GCC. This shift in focus brought about a radical move away from the one-sided view that the insured has a duty of disclosure to a more balanced approach that places a duty of enquiry upon the insurer to assist the prospective insured in considering which factors are material to the risk and to disclose these accordingly.

This shift from a one-sided duty upon the prospective insured to disclose regardless of his knowledge of insurance products, to one where the role of the insurer was also considered, was first verbalised by the court in the muchquoted case of Mahadeo $v$ Dial Direct Insurance Ltd. ${ }^{150}$ In casu, the insurer made use of a call-centre script to obtain information from the prospective insured. When a claim was later repudiated based on misrepresentation, the court sided with the policyholder, stating that the scope of the call-centre script provides an indication of the information that is indeed deemed material and that it would be wrong of the insurer to expect the policyholder to provide information outside this script and later to rely on the materiality of such non-disclosure to repudiate a claim. What is manifestly true is that the GCC supports the notion

149 See the definition of "financial product" in s 1 of the Financial Sector Regulation Act 9 of 2017. See also Millard and Hattingh The FAIS Act Explained (2016) 33-34.

150 [2008] 2 All SA 352 (W); 20084 SA 80 (W) 86B-87D. 
that insurance advisors and intermediaries have a duty to provide a service: that must be factually correct; ${ }^{151}$ that must avoid uncertainty or confusion and not be misleading; ${ }^{152}$ that must be provided in plain language, ${ }^{153}$ and, where in writing, in a clear and readable print size, spacing and format; ${ }^{154}$ that must be be adequate and appropriate in the circumstances; ${ }^{155}$ that must be provided timeously so as to afford the client reasonably sufficient time to make an informed decision; ${ }^{156}$ that must be rendered in accordance with the contractual relationship and reasonable requests or instructions of the client; ${ }^{157}$ that must be executed as soon as reasonably possible and with the interest of the client in mind; and that must be accorded priority over any interest of the provider. ${ }^{158}$

Another part of the GCC that applies to the provision of insurance is clause 15 , which regulates the conduct of direct marketers and contains several requirements relating to the information that must be provided to a prospective insured. ${ }^{159}$

151 s $3(1)(a)(i)$ of the FAIS GCC.

152 s 3(1)(a)(ii).

153 ibid.

154 s $3(1)(a)(v i)$ of the FAIS GCC.

155 s $3(1)(a)($ iii).

156 s $3(1)$ (a)(iv).

157 s $3(1)(a)(v)$.

158 s $3(1)(\mathrm{d})$

159 See s 15(1) and (2) which read as follows: “(1) A direct marketer must, when rendering a financial service to or on behalf of a client, at the earliest reasonable opportunity furnish the client with the following particulars: a) the business or trade name of the direct marketer; b) confirmation whether the direct marketer is a licensed financial service provider and details of the financial services which the direct marketer is authorised to provide in terms of the relevant license and any conditions or restrictions applicable thereto; c) telephone contact details of direct marketer (unless the contact was initiated by the client); d) telephone contact details of the compliance department of the direct marketer; e) whether the direct marketer holds professional and indemnity insurance; Provided that where the direct marketer is a representative, the information contemplated in sub-paragraphs (a) to (c) above must be provided in respect of the provider to which the representative is contracted. (2) When providing a client with advice in respect of a product, a direct marketer must at the earliest reasonable opportunity: a) make enquiries to establish whether the financial product or products concerned will be appropriate, regard being had to the client's risk profile and financial needs, and circumstances; b) furnish the client with the following particulars where appropriate: i) business or trade name of the product supplier; ii) legal status and relationship with product supplier; iii) the following details in respect of the product: (aa) Name, class or type of financial product concerned; (bb) Nature and extent of benefits to be provided; (cc) Manner in which such benefits are derived or calculated, with specific reference to the underlying assets of any investment component and the manner in which the value of such investment component is determined; (dd) Monetary obligations assumed by the client as well as manner of payment; (ee) Whether cooling off rights are offered and, if so, procedures for the exercise of such rights; (ft) Any material investment or other risks associated with the product; $c$ ) when advising or being advised by a client that the financial product concerned is to replace an existing financial product held by the client, inform the client of actual and potential financial implications, costs and consequence set out in clause $8(1)(d)$ of this Code before any transaction is concluded". 
It is evident that the primary purpose of the GCC is to force financial services providers to make full and frank disclosures to clients and it is suggested that it is no longer possible for insurance companies to sell products in a "take it or leave it" fashion, only to subsequently rely on misrepresentation to repudiate claims. This, in fact, signals a whole new dispensation in insurance where consumer vulnerability is addressed by statutory measures that are aimed at re-balancing the interests of the insurer and the policyholder. There can be no doubt that the FAIS Act was very important in levelling the playing field between the insurer and the insured. The main question that remains is what the apparent shift in responsibilities from the insured to the insurer means and, to that end, the following two paragraphs provide an exposition of the PPRs and the IA.

\section{The 2018 Policyholder Protection Rules}

The PPRs in terms of both Acts (the LTIA and STIA) were first published in $2004^{160}$ in order to provide for issues such as rules for direct marketers, ${ }^{161}$ void provisions ${ }^{162}$ and general rules ${ }^{163}$ regulating the agreement between the insurer and the policyholder. These rules were promulgated in order to provide for the notion of fairness in relation to certain issues surrounding the relationship between insurer and policyholder. Since the rules were promulgated in 2004, there have beefn some significant reforms. The most noteworthy reform was in 2010 with regard to time-bar clauses, following the decision of the Constitutional Court in Barkhuizen v Napier. ${ }^{164}$ The outcome of the case led to an amendment of the PPRs, at that time in terms of both the LTIA and the STIA, aimed at ensuring more manageable time frames for the institution of claims against insurers. ${ }^{165}$ The PPRs have over the years become a well-known tool to safeguard the rights of

160 GN 1128 in GG 26853 of 30-09-2004 (PPRs for short-term insurance); GN 1129 in GG 26854 of 30-09-2004 (PPRs for long-term insurance).

161 rule 4.

162 rule 5.

163 rule 6.

16420077 BCLR 691 (CC). The case saw the incorporation of rule 7.4 of the PPRs, that entered into force on 1 January 2010 and states that any time limitation provision may not include the 90-day period within which the insured may make representations to the insurer and must provide for a period of not less than six months after the expiry of the 90-day period for the institution of legal action.

165 See rule 7.4 of the 2010 PPRs. 
policyholders and to provide protection where common law and the principles of contract, including good faith, have not yielded equitable results. The value of the PPRs has therefore been significant. In addition, while the GCC applies to all financial products, the PPRs apply only to insurance. Furthermore, even though the rules on the pre-contractual duties of insurers as financial services providers have been heralded as infusing fairness into the pre-contractual phase, as illustrated in paragraph 5.4 above, the PPRs as product-specific market regulation were also due for an update in light of the Twin Peaks reforms of the financial services industry that was initiated by the Financial Services Regulation Act (FSRA Act). ${ }^{166}$

The new PPRs came into effect on 1 January 2018. ${ }^{167}$ The principle of treating customers fairly ("TCF") is embedded in them and their main theme is to ensure that insurers treat customers fairly throughout the product life cycle. It is submitted that, although this is an important aspect of consumer protection and should under no circumstances be trivialised as a tool that achieves a better balance between insurers and consumers, at the same time it labours from the premises that all consumers are vulnerable and in need of protection. However, while well-established, commercial mariners are perhaps not vulnerable. At the same time, it is evident from the Insurance Act that marine insurance is not only available to commercial ventures, but also to individuals who use watercraft for personal purposes. It is even possible for subsistence fishers to obtain microinsurance policies insuring small risks and limited to a lower amount. Regardless of the nature and extent of the enterprise, the 2018 PPRs adopted in terms of STIA provide for extensive disclosures before, during and after the conclusion of an insurance contract. This may be an indication that good faith is no longer a precontractual duty only, but now extends to the contractual relationship and beyond.

As far as pre-contractual disclosures are concerned, it is evident that, even though insurance companies already have duties to assist prospective insureds in disclosing facts material to the risk during the pre-contractual stage according to the FAIS Act, the 2018 PPRs expect even more of insurance companies during

\footnotetext{
1669 of 2017. See also in this regard Millard and Maholo "Market conduct regulation in perspective: Triumphs and tribulations post Twin Peaks" in Hugo and Möllers (eds) Legal Certainty and Fundamental Rights: A Cross-Disciplinary Approach to Constitutional Principles in German and South African Law (2020 - forthcoming).
}

167 GN 1433 in GG 41329 of 15-12-2017. 
this stage. The duties set out in rule 11 are stipulated in no uncertain terms. Rule 11.3.1 stipulates that any communication by an insurer to a policyholder in relation to a policy must be in plain language, ${ }^{168}$ must not be misleading, ${ }^{169}$ must be provided using an appropriate medium, taking into account the complexity of the information being provided, ${ }^{170}$ and, where applicable, must be in clear and readable print size, spacing and format. ${ }^{171}$ Additionally, the rule states that the basis of calculation "in respect of any amount, sum, premium, value, charge, fee, remuneration or monetary obligation mentioned or referred to therein, [must] be stated in actual monetary terms" and must be clearly and appropriately described. ${ }^{172}$ Insurers have the additional duty to ensure that a prospective policyholder receives all the information in good time in order to enable the policyholder to make an informed decision on whether or not to enter into a contract. ${ }^{173}$ Rule 11.3.4 further requires insurers to ensure that the information provided enables the policyholder to understand whether the proposed product meets the policyholder's requirements. This, no doubt, poses a challenge. When determining the level of information to be disclosed, the insurer must consider: "the factually established or reasonably assumed knowledge and experience of the policyholder or average targeted policyholder at whom the communication is targeted"; ${ }^{174}$ the policy terms and conditions, including the main benefits, exclusions, limitations, conditions and its duration; ${ }^{175}$ the policy's overall complexity; ${ }^{176}$ whether the same information has been provided to the policyholder previously and, if so, when. ${ }^{177}$ Where an insurer relies on a representative (intermediary or advisor) to provide

168 rule $11.3 .1(a)$.

169 rule $11.3 .1(b)$.

170 rule $11.3 .1(c)$.

171 rule 11.3.1(d). The requirement to ensure that an insurer makes the questions in the proposal form clear and unambiguous has for some time been part of South African law and, in that respect, the 2018 PPRs do not add anything new to the existing legal framework. See eg British America Assurance Co v Cash Wholesale 1932 AD 7074 and Mahadeo v Dial Direct Insurance 20084 SA 80 (W). The latter case did not deal with a printed application form, but with a contract that came into existence telephonically. The same principle, however, applies because questions posed orally must similarly be clear and unambiguous.

172 rule $11.3 .1(e)$.

173 rule 11.3 .2 .

174 rule $11.3 .4(a)$.

175 rule $11.3 .4(b)$.

176 rule $11.3 .4(c)$.

177 rule $11.3 .4(d)$. 
any information, the insurer remains responsible to ensure that the information required by rule 11 is communicated to the insured. ${ }^{178}$

In addition to these considerations, rule 11.4 .2 is very specific about what needs to be disclosed. It provides as follows:

"An insurer must provide a policyholder with the following information-

(a) the name of the insurer and its contact details;

(b) the type of policy and a reasonable and appropriate general explanation of the relevant policy;

(c) the nature and extent of policy benefits, including, where applicable, when the insurance cover begins and ends, and a description of the risk insured by the policy;

(d) concise details of all of the following, where applicable-

(i) any charges or fees to be levied against the policy or the premium;

(ii) any commission or remuneration payable to any intermediary or binder holder in relation to the policy, and the recipient thereof; and

(iii) any excesses that may become payable by the policyholder, the circumstances under which it will be payable and the consequences of not paying;

(e) in respect of premiums-

(i) the premium that is payable under the policy;

(ii) the frequency at which the premium is payable;

(iii) details of any premium increases, including the frequency and basis thereof;

(iv) whether an increase will be linked to any commensurate increase in policy benefits and any options relating to premium increases that the policyholder may select;

(v) the implications of a failure to pay a premium at the frequency referred to in subparagraph (ii); and

(vi) in the case of policies where the premium (with or without contractual escalations) is not guaranteed for the full term of the policy, the period for which the premium is guaranteed, including the frequency at which or the circumstances

178 rule 11.3 .6 
in which a review will take place;

(f) what cooling-off rights are offered and procedures for the exercise thereof;

(g) concise details of any significant exclusions or limitations, which information must be provided prominently as contemplated in rule 10.15;

(h) where a policy is entered into in connection with other goods or services (a bundled product), the premium payable in respect of the policy separately from any other prices for such other goods and services and whether entering into the policy or any policy benefit is a prerequisite for entering into or being eligible for any other goods or services;

(i) if the policy to be entered into is a consumer credit insurance policy the insurer must, where this information is known or should reasonably be known to the insurer, disclose to the policyholder whether the policy is a mandatory or optional credit life insurance policy and the difference between the two;

(j) the existence of any circumstance that could give rise to an actual or potential conflict of interest in dealing with the policyholder;

(k) any obligation to disclose material facts, including information to ensure that a policyholder knows what must be disclosed as well as the consequences of non-compliance with the obligations;

(l) where applicable, the right to request recordings of any telephonic disclosures; and

(m) the right to complain, including details on how and where to complain and the contact details of the insurer and contact details of the relevant ombud". ${ }^{179}$

This rule is quoted verbatim to illustrate how extensive the duties of disclosure are. Overall, it is crucial to note that the disclosure of material facts is but one of the many duties placed on insurers. Rule 11.4.2(k), which deals with material disclosures, is therefore but one of the many rules that have changed the way in which misrepresentation should henceforth be viewed. It is therefore argued that the requirements for misrepresentation and good faith have now been codified and, although insurers are still able to repudiate claims and cancel contracts where a material misrepresentation was made, it is submitted that any failure to comply with this particular rule will lead to an insurer not being able to cancel an insurance contract. It seems that the duty of a prospective policyholder to disclose

179 own emphasis. 
has become a duty of an insurer to inform a prospective policyholder that he has a duty to disclose certain information! It will be accurate to conclude that the duty to disclose and the pre-contractual duty of good faith still exist, but that insurers have an active role to play in ensuring that the risk is properly assessed and an appropriate premium is charged.

\section{Insurance Act, 2017}

As stated above, the IA came into operation on 1 July 2018. Although the IA is primarily aimed at establishing a prudential framework for insurance, with the majority of market-conduct regulation still seated in the LTIA and STIA (the 2018 PPRs) and in the FAIS Act, the IA did bring about changes to the law pertaining to misrepresentation and insurance warranties. ${ }^{180}$ When the IA came into operation, the notice of commencement excluded the repeal of section 53 of the STIA. ${ }^{181}$ What is also crucial is that the amendments to the Short-term PPRs that were promulgated on 28 September 2018 did not include a new rule on misrepresentation. ${ }^{182}$ This means that section 53 of the STIA remains in place amidst the new, stringent rules on disclosures that are found in rules 1 and 11 of the short-term insurance PPRs ${ }^{183}$ and in the GCC in terms of the FAIS Act. The undeniable truth is that insurance companies have pre-contractual duties towards policyholders and that failure to guide prospective insurers to disclose what insurers deem as material is in fact against the PPRs and the GCC. Although the current

180 This is clear from the objectives of the statute, which are " $[\mathrm{t}] \mathrm{o}$ provide for a legal framework for the prudential regulation and supervision of insurance business in the Republic that is consistent with the Constitution of the Republic of South Africa, 1996, and promotes the maintenance of a fair, safe and stable insurance market; to introduce a legal framework for microinsurance to promote financial inclusion; to replace certain parts of the Longterm Insurance Act, 1998, and the Short-term Insurance Act, 1998; and to provide for matters connected therewith". See also Millard (2018) 21 Juta's Insurance L Bul 51.

181 GN 639 in GG 41735 of 27-06-2018.

182 See GN 996 in GG 41928 of 28-09-2018.

183 The position for non-life insurance (long-term insurance), however, is different. Donnelly "Do you always get something out? The impact of the Insurance Act 18 of 2017 and revised policyholder protection rules on material misrepresentation and non-disclosure" 2018 SALJ 593597 explains that section 59 of the LTIA was repealed by a second notice of commencement three months after the IA came into force (1 October 2018 (GN 1020 in GG 41947 of 28-09-2018)). The legislature simultaneously promulgated the second tranche of amendments to the Long-term PPRs (GN 997 in GG 41928 of 28-09-2018). This means that the Long-term PPRs currently contain a new rule 21 on misrepresentation, which became effective on 1 October 2018 and that the all-important aspect of non-disclosure in life insurance is currently regulated by subordinate legislation. It is not clear why this distinction is made between life and non-life insurance, such as marine insurance. 
legal position is highly contentious, it is submitted that it better balances the rights of insurers and policyholders.

In the final instance, it submitted that it is patently evident that good faith in South African law is not a separate requirement for the validity of a contract and that breach of good faith alone rarely provides a suitable remedy, such as cancellation of a contract. The latest statutory framework stresses the idea that insurance contracts are contracts in good faith. However, the shift that has taken place is that the duty to disclose material information, which still rests on the policyholder, cannot be used as a weapon to repudiate as many claims as possible. Rather, the insurer has an active duty to guide a policyholder to understand which facts are likely to be material to the risk and why, thereby ensuring that the correct cover is sold at the correct price. ${ }^{184}$

\section{CONCLUSION}

It is accordingly clear that English law and South African law illustrate two significantly different lines of development. English law retained utmost good faith in marine insurance and South African law developed good faith from a pre-contractual duty to a statutory, shared responsibility between insurers and policyholders but with a very strong consumer-oriented focus. It is further submitted that the tried and trusted section 53(1)(a) of the STIA, the current GCC and the 2018 PPRs are aimed at personal and commercial insurance alike and do not "scale" the duty of good faith according to the size of the insurable interest or it being a commercial or personal one.

In terms of the duty of good faith, it appears as if the rigid and strict approach in England in codifying the duty of utmost good faith led to unfair results and generated much criticism, which necessitated law reform. The majority of law reforms evidently changed the remedy for non-compliance with the duty as well as the disclosure requirements of a policyholder, thereby constituting a fairer balance between insurers and policyholders, with more equitable results for both parties. This means that, in England, the duty of utmost good faith, although

184 Donnelly (n 183) 607. 
retaining its essence as highlighted in the MIA, has developed through reform to achieve a fairer dispensation. The remedy and disclosure requirements in England now show a closer resemblance to those in South Africa.

In South Africa, the duty of good faith remains a common law, precontractual duty on both parties. In the past, misrepresentation was often used by insurers to avoid paying claims and prospective policyholders received no guidance as to what would generally be considered material to the risk to be insured. Save for the now repealed section 59 of the LTIA ${ }^{185}$ and section 53 of the STIA, no other statutory measures existed until the FAIS Act was introduced and much more was made of the role of advisors and intermediaries at the precontractual stage, especially in ensuring that insurers take on the correct risks. It is only with the promulgation of the 2018 PPRs that it became patently clear that the age-old concept of good faith currently has a strong, statutory element to it in that, in England and in South Africa, various rules have been enacted to emphasise the duties of insurers to explain the importance of pre-contractual representations pertaining to the risk. ${ }^{186}$ In both jurisdictions, marine and other insurance contracts are subject to consumer-oriented rules that better balance the parties' respective duties of good faith towards each other. This supports the conclusion that insurers (and insurance agents) must act in good faith as well. Furthermore, while the absence of good faith never provided an aggrieved party with a remedy in South Africa, the breach of any of the rules in the PPRs or the GCC does provide remedies, based on the effect of such breach.

In conclusion, it can be said that insurance business has changed dramatically from the decision in Carter $v$ Boehm. Although utmost good faith is alive and well in England, it is submitted that the content of the doctrine has changed for the better. In South Africa, good faith in insurance continues to play an important role, albeit in a new and evolving statutory context.

185 Note that the content of section 59 has now been moved to rule 21 of the PPRs in terms of the LTIA and that it still corresponds with section 53 of the STIA.

186 Donnelly (n 183) 604. 